\title{
Proximate and Mineral Composition Variability in Ethiopian Yam (Dioscorea spp)
}

\author{
Atnafua Bekele ${ }^{1}$, Endashaw Bekele ${ }^{2}$ \\ ${ }^{1}$ South Agricultural Research Institute, Hawasa Agricultural Research Centre, Hawasa, Ethiopia \\ ${ }^{2}$ Cellular and Molecular Biology Department, Addis Ababa Universities, Addis Ababa, Ethiopia
}

Email address:

Atnaf_ruth@yahoo.com(A. Bekele)

To cite this article:

Atnafua Bekele, Endashaw Bekele. Proximate and Mineral Composition Variability in Ethiopian Yam (Dioscorea spp). Journal of Food and Nutrition Sciences. Vol. 6, No. 1, 2018, pp. 12-17. doi: 10.11648/j.jfns.20180601.12

Received: May 26, 2017; Accepted: August 14, 2017; Published: December 20, 2017

\begin{abstract}
Fourty two yam (Dioscorea species) sprouted tubers were collected from six different major growing regions of Ethiopia and planted at Hawasa Agricultural Research Center. The Dioscorea species considered in this study were $D$. bulbifera, D. abyssinica, D. cayenensis, D. rotundata, D. praehensilis, and D. alata. Five Proximate compositions (moisture, ash, crude fat, crude protein and crude fibre) and four minerals content (calcium, phosphorous, zinc and iron) were determined from $100 \mathrm{~g}$ yam tubers at Ethiopian Health and Nutrition Research Insititute (EHNRI). High variability was observed among and within yam species due to their proximate composition and mineral content. The range of protein, moisture, iron, fat, fibre, ash, zinc, calcium and phosphorous content for all the fresh yam tubers observed in the study were between $(3.13 \%$ $6.29 \%),(4.67 \%-13.57 \%),(17.21 \mathrm{mg} / 100 \mathrm{~g}$ - $90.85 \mathrm{mg} / 100 \mathrm{~g}),(0.26 \%-7.86 \%),(1.82 \%-6.36 \%),(1.68 \%-4.41 \%),(0.38$ $\mathrm{mg} / 100 \mathrm{~g}-8.33 \mathrm{mg} / 100 \mathrm{~g}),(6.3 \mathrm{mg} / 100 \mathrm{~g}-121.26 \mathrm{mg} / 100 \mathrm{~g})$ and $(8.72 \mathrm{mg} / 100 \mathrm{~g}$. $-56.12 \mathrm{mg} / 100 \mathrm{~g})$ respectively. The correlation study indicated that presence of significance association between nutritional content to some yam agronomic traits.
\end{abstract}

Keywords: Dioscorea, Proximate, Mineral, Correlation

\section{Introduction}

Roots and tuber crops refer to any growing plant that stores edible material in subterranean root, corm and tuber. The nutritional value of roots and tubers lies in their potential ability to provide one of the cheapest sources of dietary energy in the form of carbohydrates in developing countries [1].

Yam is cultivated mainly for its tuber. The tubers have a dual agricultural function. It is used as source of food and as a planting material $[2 ; 3]$. The most common use of yam is as a boiled vegetable with some kind of sauce, but the skin is not eaten. It may be removed before or after boiling. In West Africa, yam is often pounded into a thick paste after boiling and is eaten with soup [4]. Yam is also processed into flour. It may also be baked, fried, roasted or mashed to suit regional tastes and customs. However, other specific ways of preparing yam can be found in other regions [5].

Root and tuber crops are widely cultivated in southern Ethiopia. They have a vital role in supporting the population as source of food. There are various ways of yam preparation for food in respect to differences in its growing regions of the country. At Sheko districts, south west of Ethiopia, cooking methods relate to the gender of the cooker [6].

Men prepare a yam either in the field or at home. If he is single, first he cleans the tuber and roasts up the wild yam as a full meal or prepares it as late afternoon snack for his family. However, women prepare yam by steaming to get a family meal. They will harvest one or two large stake yams and peel them. Peeling should be done in doors or in the shade in order to prevent discoloured [6].

The human body requires minerals and trace elements for its biological and Physiological processes. Minerals include compounds of the elements calcium, magnesium, phosphorous, sodium, potassium, sulphur and chlorine. Trace elements that are necessary for human health include iron, iodine, copper, manganese, zinc, molybdenum, selenium, and chromium. The daily requirement of minerals and trace elements in the human diet is greater and, less than 100 milligram respectively [7]. Considering to this, the present study was conducted in order to identify extent of Ethiopian yam (Dioscorea spp) nutrient contents variability for their efficient 
use, future conservation and improvement activities.

\section{Materials and Methods}

\subsection{Samples Preparation}

Six Dioscorea species of sprouted yam tubers namely $D$. bulbifera, D. abyssinica, D. cayenensis, D. rotundata, D. praehensilis, and D. alata were collected from major yam growing regions of Ethiopia where from Gedio, Gamogofa, Wolita, Dauro, Wolega and Jima for nutritional analysis during early March to the end of April, 2010. These collected sprouted tubers were planted in randomized complete block design at Hawasa Agricultural Research Center. These collected tuber samples with their respective collection area, vernacular name and species were indicated in (Table 2).

\subsection{Proximate and Minerals Analyses}

Tubers weighing $100 \mathrm{~g}$. were peeled, cut into small cubes. Based on the scheme described by Lape and Treche, these samples were dried in an air convection oven at $60^{\circ} \mathrm{C}$ for 72 hours (8) and kept at $-20^{\circ} \mathrm{C}$ refrigerator. After drying, the samples were ground to powder and stored in air tight bottles at room temprature before analysis. Proximate composition (ash, crude fat, crude protein, and crude fibre) and minerals content (calcium, phosphorous, Zinc and iron) were determined at the Ethiopian Health and Nutrition Research Insititute (EHNRI).

\subsection{Moisture Determination}

Before drying the samples $5 \mathrm{~g}$. - $10 \mathrm{~g}$. of each fresh sample was weighed in a previously dried glass box. The samples were dried in a thermostatically controlled oven at $105^{\circ} \mathrm{C}$ for 24 hours. The dried samples in a glass box were placed in a desiccator to cool and their weight was recorded. The moisture content was calculated and expressed as a percentage of the initial weight of samples as indicated below.

$$
\% \text { moisture }=\frac{(\mathrm{W} 1-\mathrm{W} 2)}{\mathrm{SW}} \times 100
$$

Where W1 means weight of glass box and fresh sample, W2 means weight of dry sample and glass box, Sw means sample weight consists of fresh sample weight plus glass weight.

\subsection{Protein Determination}

In the present study, nitrogen content was estimated by Kjeldhal analysisis and Crude protein content was calculated by multiplying the nitrogen content by a factor of 6.25 .

\subsection{Fibre Determination}

Crude fiber content was determined by Weende scheme. The dried sample was boiled for 30 minutes in dilute sulphuric acid and filtered. This residue was again boiled in sodium hydroxide. The insoluble residue consisted of crude fibre and ash. This resdue was burned and the weight difference was taken as crude fibre.

\subsection{Fat and Minerals Determination}

Fat content in food sample was determined by solxet (Diethyl ether) method. The dried sample was extracted with ether. This ether extract gave crude fat. The amount of trace elements in yam samples were determined by flame atomic absorption spectrometry (FAAS). In this method, the organic material was removed by dry ashing. The residue was dissolved in dilute acid. The solution was sprayed in to the FAAS. The absorbtion of the metal was analyzed and measured at a specific wave length.

\subsection{Statistical Analysis}

The Pearson correlation coefficient was used to estimate the relationships among average stem height, average number of leaves at 30 days of emergence, average tuber yield, proximate compositions and mineral contents of the 42 yam germplasms using the computer program Gen Stat (discovery edition 3).

Table 1. Nutritional Parameters considered for present study.

\begin{tabular}{lll}
\hline SN & Nutritional parameters & Units \\
\hline 1 & Crude Fat & Percent of total \\
2 & Crude Protein & Percent of total \\
3 & Crude Fibre & Percent of total \\
4 & Moisture & Percent of total \\
5 & Ash & Percent of total \\
6 & Iron & $\mathrm{g} / 100 \mathrm{mg}$ \\
7 & Zinc & $\mathrm{g} / 100 \mathrm{mg}$ \\
8 & Calcium & $\mathrm{g} / 100 \mathrm{mg}$ \\
9 & Phosphorous & $\mathrm{g} / 100 \mathrm{mg}$ \\
\hline
\end{tabular}

Note: $\mathrm{SN}=$ Serial Number

Table 2. Ethiopian yam (Dioscorea spp) considered for nutitional omposition study.

\begin{tabular}{llll}
\hline SN & Accessions Code & Species & Region \\
\hline 1 & Ged 05 & D. abyssinica & Gedio \\
2 & Wol 10 & D. abyssinica & Wolayita \\
3 & GG02 & D. abyssinica & Gamogofa \\
4 & GG03 & D. abyssinica & Gamogofa \\
5 & GG04 & D. abyssinica & Gamogofa \\
6 & GG05 & D. abyssinica & Gamogofa \\
7 & GG06 & D. abyssinica & Gamogofa \\
8 & GG07 & D. abyssinica & Gamogofa \\
9 & GG08 & D cayenensis & Gamogofa \\
10 & GG09 & D cayenensis & Gamogofa \\
11 & Wol 01 & D. rotundata & Wolayita \\
12 & Wol 02 & D. rotundata & Wolayita \\
13 & Wol 03 & D. praeihensilis & Wolayita \\
14 & Wol 04 & D. praeihensilis & Wolayita \\
15 & Wol 05 & D. rotundata & Wolayita \\
16 & Dau 01 & D. bulbifera & Dauro \\
17 & Dau 02 & D. bulbifera & Dauro \\
18 & Dau 03 & D. abyssinica & Dauro \\
19 & Dau 04 & D. abyssinica & Dauro \\
20 & Wol 06 & D. praeihensilis & Wolayita \\
21 & Wol 07 & D. praeihensilis & Wolayita \\
22 & GG 01 & D. praeihensilis & Gamogofa \\
23 & Wol 08 & D. abyssinica & Wolayita \\
\hline
\end{tabular}




\begin{tabular}{llll}
\hline 24 & Wol 09 & D. abyssinica & Wolayita \\
25 & Wolg 01 & D. abyssinica & Wolayita \\
26 & Wolg 02 & D. rotundata & Wolayita \\
27 & Jim 02 & D. alata & Jima \\
28 & Jim 03 & D. alata & Jima \\
29 & Wolg 03 & D. rotundata & Wolega \\
30 & Wolg 04 & D. rotundata & Wolega \\
31 & Jim 04 & D. bulbifera & Jima \\
32 & Jim 05 & D. bulbifera & Jima \\
33 & Wolg 05 & D. bulbifera & Wolega \\
34 & Wolg 06 & D. bulbifera & Wolega \\
35 & Jim 06 & D. alata & Jima \\
36 & Jim 07 & D. alata & Jima \\
37 & Ged 02 & D. bulbifera & Gedio \\
38 & Ged 03 & D. bulbifera & Gedio \\
39 & Ged 04 & D.bulbifera & Gedio \\
40 & Ged 05 & D. bulbifera & Gedio \\
41 & Wolg 07 & D.bulbifera & Wolega \\
42 & Wolg 08 & D. bulbifera & Wolega \\
\hline
\end{tabular}

\section{Results and Discussions}

\subsection{Proximate and Mineral Composition Variability Among Yam (Dioscorea spp) of Ethiopia}

In the present study, yam species showed variations with respect to proximate composition and mineral content. Generaly moisture content was highest and they have high nutritional content with respect to crude protein and crude fibre whereas they showed relatively low ash and fat content (Figure 1). Simillarly high calcium and iron content was recorded but relatively the phosphorous and Zinc content was low (Figure 2). Earlier studies indicated presence of high calcium content in yam and in contrary its' low Zinc content $[9 ; 10]$. There is a previous report which stated that yam has low calcium content [11]. However, in general this study resulted Ethiopian yams have highest nutritional content compared to earlier reports of West Africa with respect to calcium, iron, protein and fibre $[12 ; 13]$.

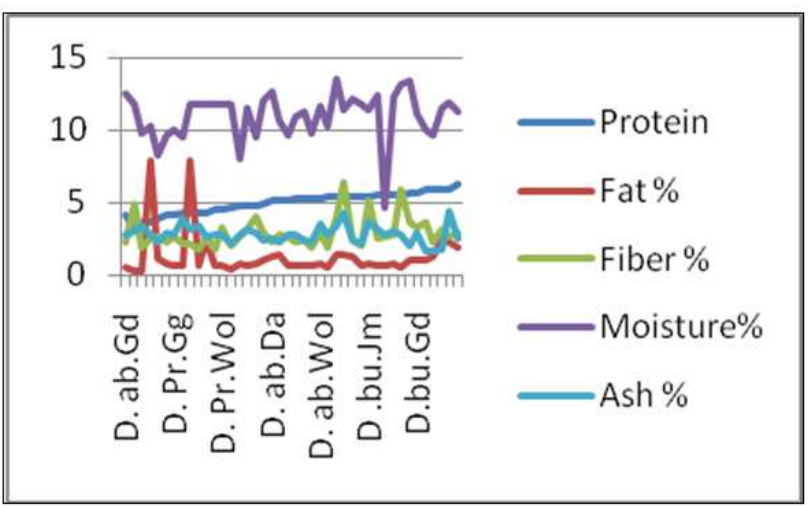

Figure 1. Comparison of Proximate Compositions in 100g. Edible Portion of Yam (Dioscorea spp).

Notes:- D.ab $=$ D. abyssinica, D.bu=D. bulbifera, D.ca $=$ D. cayenensis, D.pr $=$ D.preahensilis, $\mathrm{D} \cdot \mathrm{rot}=D$. rotundata, $\mathrm{D} \cdot \mathrm{al}=D$. alata $\mathrm{Wol}=$ Wolita, $\mathrm{Gd}=$ Gedio, Da=Dauro, Jm= Jima, $\mathrm{Ga}=$ Gamogofa, wlg= Wolega

\subsubsection{Crude Protein Content (\%)}

Average performance for protein was higer in D. alata and D. bulbifera (Figure 1). The range of protein content for all the fresh tubers observed in the study was between $3.13 \%$ to $6.29 \%$. D. bulbiferas pecies from Wolega region recorded the highest protien content $(6.29 \%)$ compared to all other yam species and $D$. abyssinica from Kembata revealed minimum value $(3.13 \%)$. However, the range of crude protein content was greater among $D$. abyssinica species $(3.13 \%-5.37 \%)$ in comparison to $D$. praehensilis $(3.64 \%-5.22 \%)$, D. cayenensis (4.24\%-4.27\%), D. rotundata $(4.29 \%-5.43 \%)$ and D. alata $(5.39 \%-5.70 \%)$

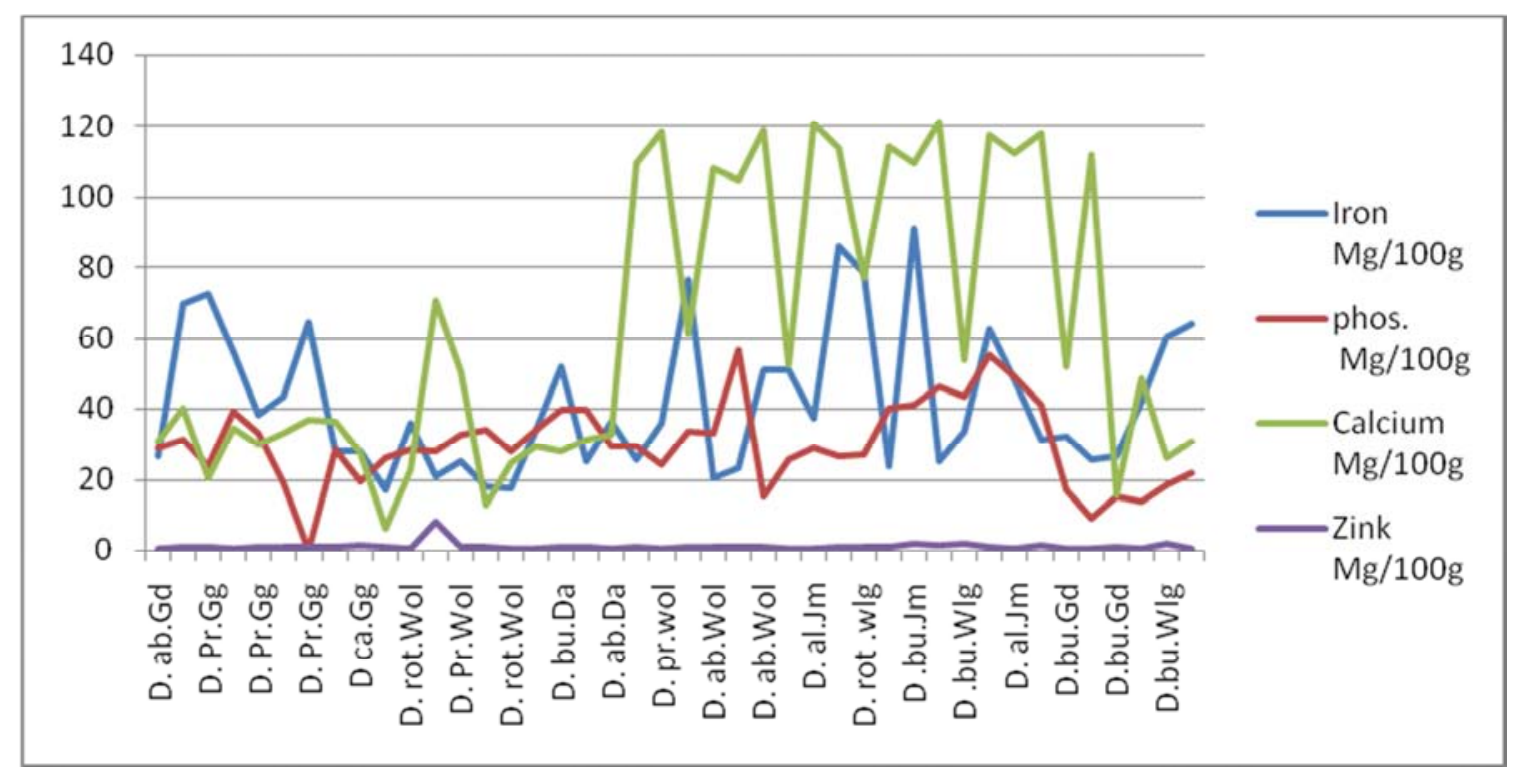

Figure 2. Comparison of Minerals Content in 100g. Edible Portion of yam (Dioscorea spp).

Notes:-D.ab $=$ D. abyssinica, D.bu=D. bulbifera, D.ca $=$ D. cayenensis, D.pr=D. preahensilis, D.rot $=$ D. rotundata, D.al $=$ D.alata Wol $=$ Wolita, Wlg $=$ Wolega, $\mathrm{Da}=$ Dauro, $\mathrm{Jm}=$ Jima, Ga=Gamogofa 
Table 3. Range of Proximates composition of Yam (Dioscorea species) from Ethiopia.

\begin{tabular}{llllll}
\hline Yam (Dioscorea Species) & \multicolumn{1}{l}{} \\
\hline nutrient (\%) & $\mathbf{1}$ & $\mathbf{2}$ & $\mathbf{3}$ & $\mathbf{4}$ & $\mathbf{5}$ \\
\hline Protein & $5.39-5.70$ & $4.29-5.43$ & $4.47-6.29$ & $4.24-4.27$ & $3.13-5.37$ \\
Fat & $0.5-1.42$ & $0.63-2.37$ & $0.59-2.46$ & $0.59-7.86$ & $0.31-1.22$ \\
Fibre & $3.65-6.36$ & $2.12-2.19$ & $1.82-5.16$ & $1.87-2.13$ & $1.94-4.91$ \\
Moisture & $9.83-13.57$ & $8.08-12.17$ & $4.67-12.41$ & 11.85 & $0.26-7.83$ \\
Ash & $2.05-4.29$ & $2.13-2.76$ & $1.68-4.41$ & $3.22-3.47$ & $9.83-12.71$ \\
\hline
\end{tabular}

Note:- $1=\mathrm{D}$. alata; $2=\mathrm{D}$. rotundata; $3=\mathrm{D}$. Bulbifera $4=\mathrm{D}$. cayenensis $5=\mathrm{D}$. abyssinica $6=\mathrm{D}$. preahensilis

This result is in line with other research reports which indicated nutritional content of yam varies with species [14]. It is also indicated that, the mean protein content of aerial yam is higher than the protein value of sweet potato, potato, cassava, taro and plantain [15]. Similarly, It is reported that presence of higher protein contents in yam tuber compared to other tropical root and tuber crops like cassava, sweet potato and taro which highlight its' nutritional superiority as a staple food $[10 ; 14 ; 16 ; 17]$. Yam proteins have a better amino acid balance compared to other tropical root crops [18].

\subsubsection{Crude Fat Content (\%)}

D. cayenensis from Gamogofa origin recorded highest fat content $(7.86 \%)$ followed by $D$. preahensilis of same orign (7.83\%) compared to all other species. The range for fat content was also greater among $D$. preahensilis $(0.26 \%$ $7.83 \%)$ and D. cayenensis $(0.59 \%-7.86 \%)$.

\subsubsection{Crude Fibre Content (\%)}

Average fibre content was higher for $D$. alata species followed by $D$. bulbifera. The range of fibre content was $(1.82 \%-6.36 \%)$ for all samples considered in the study. The lowest fibre content was recorded from $D$. bulbifera of Wolayita orign. The range of fibre content was high as observed from D. bulbifera $(1.82 \%-5.16 \%)$, D. alata $(3.65 \%$ $6.36 \%)$ and D. abysinica $(1.94 \%-4.91 \%)$.

\subsubsection{Moisture Content (\%)}

Generally, this study revealed that presence of high moisture content in yam species. The presence of high content of moisture in yam is an indication of existence of good source of minerals [13]. The range for moisture content was between (4.67\%-13.57\%) for all samples studied (Figure
1). D. alata from Jima region and D. bulbifera from Wolega region scored the highest and lowest moisture content respectively. $D$. bulbifera had the highest range of moisture content $(4.67 \%-12.41 \%)$ followed by $D$. rotundata $(8.08 \%$ $12.17 \%$ ) and D. preahensilis $(8.37 \%-11.85 \%)$ (Table 3$)$.

\subsubsection{Iron Content (mg/100g)}

The range of iron content revealed from all samples was (17.21 mg/100g - $90.85 \mathrm{mg} / 100 \mathrm{~g})$. The highest iron content recorded from species $D$. bulbifera from Jima region $(90.85$ $\mathrm{mg} / 100 \mathrm{~g}$ ) and the lowest was from $D$. cayenensis from Gamogofa $(17.21 \mathrm{mg} / 100 \mathrm{~g})$. The highest range was observed among species D. bulbifera $(20.96 \mathrm{mg} / 100 \mathrm{~g}-90.85 \mathrm{mg} / 100 \mathrm{~g})$ followed by $D$. rotundata $(17.75 \mathrm{mg} / 100 \mathrm{~g}-78.29 \mathrm{mg} / 100 \mathrm{~g})$ and D. Preahensilis (18.36 mg/100g -76.36 mg/100g).

\subsubsection{Ash (\%) Content}

The highest value (4.41\%) and lowest value (1.68\%) of ash content was recorded from $D$. bulbifera species from Wolega and Gedio region respectively (Table 3). Average ash content was higher for $D$. cayenensis $(3.34 \%)$ followed by $D$. alata $(3.16 \%)$ and D. bulbifera $(3.16 \%)$ while the lowest its' average content was obtained from $D$. rotundata $(2.5 \%)$.

\subsubsection{Zinc Content (mg/100g)}

The species $D$. bulbifera of Wolita orign recoreded greater Zinc content $(8.33 \mathrm{~g} / 100 \mathrm{mg})$ whereas D. rotundata species of same locality was lowest $(0.35 \mathrm{~g} / 100 \mathrm{mg})$. The range for Zinc content was also greater among $D$. bulbifera species $(0.4$ $\mathrm{g} / 100 \mathrm{mg}-8.33 \mathrm{~g} / 100 \mathrm{mg})$ compared to D. alata $(0.38 \mathrm{~g} / 100 \mathrm{mg}$ $-1.18 \mathrm{~g} / 100 \mathrm{mg})$, D. rotundata $(0.35 \mathrm{~g} / 100 \mathrm{mg}-1.02 \mathrm{~g} / 100 \mathrm{mg})$ D. preahensilis $(0.4 \mathrm{~g} / 100 \mathrm{mg}-1.09 \mathrm{~g} / 100 \mathrm{mg})$ and $D$. abyssinica $(0.48 \mathrm{~g} / 100 \mathrm{mg}-0.77 \mathrm{~g} / 100 \mathrm{mg})$ (Table 4).

Table 4. Range ofMinerals Content of Six yam (Dioscoreaspecies) from Ethiopia.

\begin{tabular}{|c|c|c|c|c|c|c|}
\hline \multicolumn{7}{|c|}{ Yam (Dioscorea)Species } \\
\hline \multicolumn{7}{|c|}{ Mnineral content of Dioscorea species (mg/100g) } \\
\hline & 1 & 2 & 3 & 4 & 5 & 6 \\
\hline Iron & $17.75-51.1$ & $17.75-78.29$ & $20.26-90.85$ & $17.21-27.95$ & 20.3-69.7 & $18.36-76.36$ \\
\hline Zinc & $0.38-1.18$ & $0.35-1.02$ & $0.4-8.33$ & $0.74-0.75$ & $0.48-0.77$ & 0.4-1.09 \\
\hline Calcium & 11.24-120.9 & $22.77-114.4$ & $15.74-121.3$ & $6.3-27.6$ & $31.02-118.8$ & $13.1-118.2$ \\
\hline Phosph orous & $26.59-49.12$ & $26.96-40.21$ & $8.72-55.26$ & $19.15-26.12$ & $15.1-56.5$ & $20.9-39.0$ \\
\hline
\end{tabular}

Note:- $1=D$. alata, $2=D$. rotundata, $3=D$. Bulbifera, $4=D$. Cayenensis, $5=D$. abyssinica, $6=D$. preahensilis

\subsubsection{Calcium Content (mg/100g)}

The highest calcium content was obtained from species $D$. bulbifera of Jima orign $(121.3 \mathrm{mg} / 100 \mathrm{~g})$ whereas the lowest was from D. cayenensis of Gamogofa orign $(6.3 \mathrm{mg} / 100 \mathrm{~g})$ (Table 3).

\subsubsection{Phosphorous Content (mg/100g)}

The highest phosporous content was recorded from $D$. abyssinica of Wolita orign $(56.53 \mathrm{mg} / 100 \mathrm{~g})$ in contrary to the lowest value was from D. bulbifera $(8.72 \mathrm{mg} / 100 \mathrm{~g})$ of Gedio orign (Table 3 ). Average phosphorous content was high for 
species D. abyssinica $(32.34 \mathrm{mg} / 100 \mathrm{~g})$ followed by $D$. rotundata $(30.78 \mathrm{mg} / 100 \mathrm{~g})$ and D. Preahensilis $(29.48$ $\mathrm{mg} / 100 \mathrm{~g})$.

\subsubsection{Correlation Coefficients Among Yield, Nutritional Values and Some Agronomic Traits in Yam}

Significant and positive correlation coefficients (r) was found between fibre content and calcium content $\left(\mathrm{r}=0.373^{*}\right)$, iron content and ash content $(\mathrm{r}=0.413 * *)$, iron content and fibre content $\left(0.453^{* *}\right)$, phosphorous content and average stem height $\left(\mathrm{r}=0.368^{*}\right)$, average tuber yield per plot and calcium content $(\mathrm{r}=0.586 * *)$, average tuber yield per plot and fibre content $(\mathrm{r}=0.491 * *)$, average tuber yield per plot and moisture content $\left(\mathrm{r}=0.431^{* *}\right)$. Nevertheless there were no significant relationships between Zinc content, protein content, fat content, and number of leaves at 30 days after emergence as well as to the rest of the traits studied.

It is necessary to have a good knowledge about traits that have significant association with in them and to yield since the traits can be used as in direct selection criteria to increase the mean performance of varieties in a new plant population [19].

Plants absorb phosphorous in form of soluble phosphorous such as $\mathrm{H}_{3} \mathrm{PO}_{4}$ and $\mathrm{HPO}_{4}$. It present abundantly in plant growing and storage organ plus plays an important role in the energy transfer reaction, oxidation and reduction process. Stunted plant growth in young plants is one of its deficiency symptoms [20]. Calcium deficiency in yam (Dioscorea spp) mostly affects the growth of new tissue at the vine, root and tuber tips. The earliest clear symptom of calcium deficiency may be premature inactivity of the vine tips. Root growth is particularly affected by calcium deficiency. Root tips may die, resulting in a cluster of branching just behind the tip. The growing tip of the tuber is affected and tubers may be blunt ended and short [21]. The present study also revealed positive association between stem height to phosphorous content and calcium content to tuber yield which is in agreement to these particulars.

Nevertheless there was not revealed any significant relationships between Zinc content, protein content, fat content and number of leaf at 30 days after emergence and also to rest of the traits studied. Lipids are widely distributed important groups of organic substances found in plants and animals. Lipids consist of fats and their derivatives often unrelated physiologically and chemically [20]. In the present study, absence of correlation of fat content to the rest of traits studied may be due to this lack of physiological relation.

\section{Conclusion and Recommendations}

This study revealed that Ethiopian yams (Dioscorea species) are nutritionally rich. Generally, they will have important role to attain food nutrition security in the country. As indicated above, they have highest nutritional content with respect to protein, fibre calcium and iron content but comparatively ash, fat, phosporous and Zinc contents were low.

High variability was observed among and within yam species due to their proximate composition and mineral content. The maximum nutritional variation was observed in overall range within same and different species. D. alata and D. bulbifera, revealed highest mean value of protein and fibre content compared to the rest of yam species. Similarly, the range of moisture and Zinc contents was superior among germplasms of D. bulbifera. D. bulbifera of Jima origin also revealed highest calcium content.

This shows that a presence of high potential for selecting cultivars in this respect. The yellow flesh yam may be a choice for adults in its better vitamin A content and will help to improve the balanced intake of food in farming community. Hence, it is vital to study the variability of Ethiopian yam germplasms in their vitamins content and presence of association between vitamins content to yam tuber flesh colour. Indeed, the contributions of both genetic and environmental factors on yam proximate and mineral composition need to be determined across diverse environmental factors.

\section{References}

[1] Ugwu, F. (2009). The potentials of roots and tubers as wearing food. Pakistan Journal of Nutrition. 8: 1701-1705.

[2] Hahn, S. (1995). Yams. In: Evolution of crop plants, Smartt J and Simmonds NW (eds.) second edition ${ }^{6}$ Longman Group Limited, UK.

[3] Craufurd, Q., Summerfield, J., and Asiedu, R. (2006). Dormancy in yams. Expl Agric. (2001), 37: 141-181.

[4] Orkwor, G., (1998). The importance of yams. In: Food yams. Advances in research. International Institute of Tropical Agriculture, Nigeria. Orkwor GC, Opara, L. (1999). Yam storage. In: Bakker-Arkema et al. (eds). CIGR Handbook of Agricultural Engineering Volume IV Agro Processing. The American Society of Agricultural Engineers, St. Joseph, MI.

[5] Okaka, J., Okorie, P., and Ozon, O., (1991). Quality Evaluation of sun dried yam chips. Tropical Science 30: 365-275.

[6] Elisabeth Anne Hildebrand (2003). Motives and opportunities for domestication: an ethno archaeology- cal study in southwest Ethiopia. Journal of Anthropological Archaeology 22 (2003) 358-375.

[7] Ellahi, B., Salman, A. and Sheikh, S. (2007). Estimation of Nutritional Value and Trace Elements Content of Charthamus Oxyacantha, Erucasativa and Plantago Ovata, Pak. J. Bot., 39(4): 1181-1187, 2007.

[8] Lape, I. M. and Treche, S. (1994). Nutritional quality of yam (Dioscorea dumetorum and D. rotundata) flours for growing rats. J. Sci. Food Agric., 66(4): 447- 455.

[9] Esayas Ayele (2009). Effect of Boiling Temperatures on Mineral Content and Anti nutritional Factors of Yam and Taro Grown in Southern Ethiopia. A thesis for the degree of Master of Science in Food Science and Nutrition, Addis Ababa University, Addis Ababa.

[10] Wanasundera, J. and Ravindran, G. (1994). Nutritional assessment of yam (Dioscorea alata) tubers. Plant Foods for Human Nutrition 46(1), 33-39. Quoted in Jane N. (2010). Yam Nutrition, nutrient disorders and soil fertility management. Australian Centre for International Agricultural Research. 
[11] Bradbury, J., and Holloway, W. (1988). Chemistry of Tropical Root Crops: Significance for Nutrition and Agriculture in the Pacific. ACIAR Monograph, Australian Centre for International Agricultural Research.

[12] Osagie, A. and Eka, O. (1998). Chemical Composition of Root and Tuber crops. In: Nutritional quality of plant foods. Department of biochemistry, University of Benin, Nigeria.

[13] Opara, L. (1999). Yam storage. In: CIGR Handbook of Agricultural Engineering Volume IV Agro Processing. The American Society of Agricultural Engineers, St. Joseph, MI.

[14] Zinash, D. (2008). Minim izing Post harvest Losses in Yam (Dioscorea spp.). In: Using Food Science and Technology to Improve Nutrition and Promote National Development, Robertson, G. L. \& Lupien, J. R. (Eds), International Union of Food Science \& Technology.

[15] Hahn S., Osiru D., Akoroda M. \& Otoo J. (1987). Yam production and its future prospects. Outlook Agric 16: 105110 .

[16] Zinash, D. (2008). Minimizing Postharvest Losses in Yam
(Dioscorea spp.). In: Using Food Science and Technology to Improve Nutrition and Promote National Development, Robertson, G. L. \& Lupien, J. R. (Eds), International Union of Food Science \& Technology.

[17] Onwume., I. (1978). The tropical tuber crops: Yams, cassava, sweet potato and coco yams. Chichester: John Wiley \& Sons.

[18] Baquar, S., Oke, O. (1977). Mineral constituents of Nigerian Yams. Nutr Rep Int 15: 265-272.

[19] Ojo, D., Omikunle O., Oduaye O., Ajala M., Ojunbaye, S. (2006). Heritability, character correlation and path coefficient analysis among six inbred lines of maize (Zea mays L.). World Journal of Agricultural Science 2(3): 352-358, Cotonou, Benin.

[20] Pandey, S. and Sinha, B. (1999). Plant physiology, third edition, Vikas Publishing house, New Delhi, India.

[21] Jane, N. (2010). Yam Nutrition, nutrient disorders and soil fertility management. Australian Centre for International Agricultural Research. 